\title{
Correction to: Non-indigenous species along the Israeli Mediterranean coast: tally, policy, outlook
}

\author{
Bella S. Galil (1) - Henk K. Mienis • Razy Hoffman • Menachem Goren
}

Published online: 12 January 2021

(C) Springer Nature Switzerland AG 2021

\section{Correction to: \\ Hydrobiologia \\ https://doi.org/10.1007/s10750-020-04420-w}

After publication of the above mentioned article, previously undisclosed material was made available resulting in an altered population status for the below mentioned fish species:

Acanthurus coeruleus, Conus arenatus arenatus, Trivirostra triticum-Single record; Crenidens crenidens, Fistularia petimba, Notocochlis gualteriana, Pomacanthus imperator, Sardinella gibbosa, Spratelloides delicatulus,-_Rare; Diala semistriata,

Supplementary Information The online version contains supplementary material available at https:// doi.org/10.1007/s10750-020-04502-9.

The original article can be found online at https://doi.org/10. 1007/s10750-020-04420-w.

B. S. Galil $(\bowtie) \cdot$ H. K. Mienis · R. Hoffman · M. Goren The Steinhardt Museum of Natural History and Israel National Center for Biodiversity Studies, Tel Aviv University, 6997801 Tel Aviv, Israel

e-mail: bgalil@tauex.tau.ac.il

H. K. Mienis

National Natural History Collections, Hebrew University of Jerusalem, 9190401 Jerusalem, Israel

M. Goren

School of Zoology, Tel Aviv University, 6997801 Tel Aviv, Israel
Isognomon legumen, Melithaea eryhtraea, Mimachlamys sanguinea-Local; Decapterus russelli, Hemiramphus far, Pomadasys stridens, Torquigener flavimaculosus-Common; Nemipterus randalli, Ostorhinchus fasciatus-Abundant.

The changes to this species list do not alter the scientific meaning of the original publication, but it does result in an update of the original supplementary material $\mathrm{S} 1$, which is published here.

Publisher's Note Springer Nature remains neutral with regard to jurisdictional claims in published maps and institutional affiliations. 